\title{
PENINGKATAN MINAT BELAJAR ANAK YATIM PIATU DI PANTI ASUHAN FAJAR HARAPAN KOTA PEKANBARU
}

\author{
Ardiya*, Pahmi, Wandi Syahfutra, Prih Febtiningsih, Siti Niah, \\ Agung Prasetyo Wibowo \\ Pendidikan Bahasa Inggris, Fakultas Keguruan dan Ilmu Pendidikan \\ Universitas Muhammadiyah Riau \\ email: ardiya@umri.ac.id
}

\begin{abstract}
Community service carried out at the Fajar Harapan Orphanage in Pekanbaru City aims to provide counseling in increasing learning interest in the orphanage of the Fajar Harapan orphanage. The main problems faced are the low learning interest of children in orphanages, low interest in learning and a less conducive learning environment. The low interest in learning of children at the Fajar Harapan Orphanage has resulted in their performance decreasing in school and this is of course a problem for children and caregivers in this orphanage. To achieve the objectives of this community service activity, the lecture and discussion methods were used. In addition, an appropriate strategy is needed to foster children's learning interest in this orphanage, namely strategies to improve performance in schools, strategies to foster children's interest in learning and strategies to build a conducive learning environment. PPM activities that have been carried out take place smoothly in accordance with the expected plan. The participants of the activity responded positively and thanked the executor for providing useful knowledge to the participants, namely the strategy to foster interest in learning in order to improve learning achievement. Therefore they hope that this activity will not stop, but this activity will continue in the future.
\end{abstract}

Keywords: Community Service, Learning Interest, Achievement

\begin{abstract}
Abstrak
Pengabdian pada masyarakat yang dilakukan di Panti Asuhan Fajar Harapan Kota Pekanbaru bertujuan untuk memberikan penyuluhan dalam peningkatan minat belajar kepada anak yatim piatu panti asuhan Fajar Harapan. Persoalan utama yang dihadapi adalah rendahnya minat belajar anak-anak di panti asuhan, rendahnya minat belajar dan lingkungan belajar yang kurang prestasi mereka menurun di sekolah dan hal ini tentu saja menjadi masalah bagi anak-anak dan pengasuh di panti asuhan ini. Untuk mencapai tujuan dari kegiatan pengabdian pada masyarakat ini, maka digunakanlah metode ceramah dan diskusi. Selain itu juga diperlukan strategi yang tepat untuk menumbuhkan minat belajar anak-anak di panti asuhan ini yaitu strategi meningkatkan prestasi di sekolah, strategi menumbuhkan minat belajar anak-anak dan strategi membangun lingkungan belajar yang kondusif. Kegiatan PPM yang telah dilaksanakan berlangsung dengan lancar sesuai dengan yang diharapkan. Para peserta kegiatan merespon positif dan berterima kasih kepada pelaksana karena telah memberikan ilmu yang bermanfaat kepada para peserta yaitu strategi menumbuhkan minat belajar demi meningkatkan prestasi. Oleh karena itu mereka berharap kegiatan ini tidak sampai disini saja, akan tetapi kegiatan ini tetap berlanjut dimasa yang akan datang.
\end{abstract}

Kata Kunci: Pengabdian kepada Masyarakat, minat belajar, prestasi

\section{PENDAHULUAN}

Keberadaan panti asuhan sangat penting bagi anak-anak yang telah ditinggalkan orang tua mereka. Panti asuhan menjadi "pengganti rumah" untuk tempat anak-anak yatim tumbuh, belajar dan berinteraksi. Panti asuhan dapat didefinisikan sebagai rumah tempat memelihara dan merawat anak yatim (Kamus Besar Bahasa Indonesia Edisi 
Ketiga, 2005). Sedangkan Departemen Sosial RI (2004:4) menyatakan bahwa Panti Sosial Asuhan Anak adalah suatu lembaga usaha kesejahteraan sosial yang mempunyai tanggung jawab untuk memberikan pelayanan kesejahteraan sosial pada anak terlantar dengan melaksanakan penyantunan dan dan pengentasan anak terlantar, memberikan pelayanan pengganti orang tua/wali anak dalam memenuhi kebutuhan fisik, mental dan sosial kepada anak asuh sehingga memperoleh kesempatan yang luas, tepat dan memadai bagi pengembangan kepribadiannya sesuai dengan yang diharapkan sebagai bagian dari generasi penerus cita-cita bangsa dan sebagai insan yang akan turut serta aktif dalam bidang pembangunan nasional.

Panti asuhan Fajar Harapan berlokasi tidak jauh dari kampus Universitas Muhammadiyah Riau, tepatnya berada di Jln. Mustofa Yatim No.12 kelurahan Tangkerang Tengah, Kecamatan Marpoyan Damai. Panti Asuhan ini didirikan oleh Yazid Bakhri pada tanggal 18 Agustus 2003. Saat ini menampung 63 anak terdiri dari 30 bayi dan balita dan selebihnya sudah sekolah. Pihak panti asuhan Fajar Harapan menjelaskan bahwa sumber dana lebih banyak didapat dari Yayasan Bina Dhuafa dan masyarakat.

Panti asuhan ini telah menyekolahkan anak-anak hingga saat ini duduk di bangku Sekolah Menengah Atas. Panti Asuhan ini menjadi jembatan bagi anak-anak untuk menempuh jenjang pendidikan. Zaman sekarang ini pendidikan menjadi tolak ukur penting atas keberhasilan seseorang. Oleh karena itu, panti asuhan ini membekali anak-anak dengan pendidikan agar setelah dewasa mereka dapat dengan dengan bersaing dengan yang lainnya sehingga mereka mendapat pekerjaan yang layak.

Berdasarkan survei yang telah dilakukan di Panti Asuhan Fajar Harapan, telah ditemukan beberapa masalah yang dialami oleh para pengasuh dan anak asuh di Panti Asuhan. Masalah tersebut antara lain para pengasuh mengalami kesulitan dalam mengasuh dan membimbing para anak asuh, pengasuhan di panti asuhan kurang baik karena para pengasuh memandang bahwa anak asuh merupakan makhluk biologis, kurangnya minat belajar para anak panti asuhan yang sudah berada dalam jenjang pendidikan dan lingkungan panti asuhan yang kurang higienis dalam tumbuh kembang anak-anak dan balita. Faktor- faktor yang mengakibatkan para pengasuh mengalami kesulitan dalam mengasuh dan membimbing antara lain: para pengasuh kurang memahami anak asuh yang dibimbingnya. Para pengasuh harus memahami psikologis, minat dan kebutuhan anak asuh yang dibimbingnya. Mereka berasal dari latar belakang keluarga yang berbeda-beda. Oleh karena itu cara pengasuhan juga seharusnya berbeda-beda.

Salah satu persoalan utama yang dihadapi di panti asuhan adalah rendahnya minat belajar anak-anak di panti asuhan. Rendahnya minat belajar anak-anak di panti asuhan dapat mengakibatkan rendahnya prestasi belajar siswa. Sebagaimana yang dinyatakan oleh Prayitno dan Erman Amti (2004:280) bahwa salah satu aspek yang menyebabkan anak-anak perlu dibimbing adalah rendahnya minat belajarnya. Hal-hal yang menyebabkan rendahnya minat belajar anak-anak di panti asuhan antara lain pola lingkungan belajar di panti asuhan, faktor sosial individual berupa kematangan fisik, emosional dan intelektual serta faktor lingkungan sosial berupa dukungan orang tua dan guru.

Berdasarkan uraian diatas maka dapat disimpulkan bahwa masalah-masalah yang ditemukan di panti asuhan Fajar Harapan yaitu:

1. Rendahnya prestasi anak yatim piatu di sekolah

2. Rendahnya minat belajar

3. Lingkungan belajar yang kurang kondusif 


\section{METODE PENGABDIAN}

Rendahnya minat belajar anak-anak di Panti Asuhan Fajar Harapan Kelurahan Tangkerang Tengah Kecamatan Marpoyan Damai telah mengakibatkan prestasi mereka menurun di sekolah dan hal ini tentu saja menjadi masalah bagi anak-anak dan pengasuh di panti asuhan ini.

Hadis (2008: 45) menyatakan bahwa minat belajar anak/siswa dapat dipengaruhi oleh objek belajar, metode, strategi dan pendekatan pembelajaran, sikap dan perilaku guru, media pembelajaran, fasilitas pembelajaran, lingkungan belajar dan suara guru. Berdasarkan pernyataan diatas, maka untuk kegiatan ini diperlukan strategi untuk meningkatkan minat belajar anak di panti asuhan.

Strategi ini ditujukan kepada anakanak, para pengasuh dan pengurus panti asuhan. untuk menumbuhkan minat belajar anak-anak di panti asuhan ini. Sehingga diharapkan dapat meningkatkan prestasi mereka lebih baik di sekolah. Untuk mencapai tujuan pengabdian masyarakat maka akan ditempuh langkah-langkah sebagai berikut:

1. Menghubungi pimpinan Panti Asuhan

Fajar Harapan Kelurahan Tangkerang

Tengah Kecamatan Marpoyan Damai

Kota Pekanbaru untuk mendiskusikan topik yang hendak diabdikan yaitu Peningkatan Minat Belajar Anak-Anak Panti Asuhan Fajar Harapan di Kelurahan Tangkerang Tengah Kecamatan Marpoyan Damai Kota Pekanbaru dan mendata jumlah anakanak dan pengasuh panti asuhan ini sebagai calon peserta.

2. Menyelenggarakan pengabdian dengan memberikan penyuluhan tentang:

a. Strategi meningkatkan prestasi di sekolah

b. Strategi menumbuhkan minat belajar anak-anak

c. Strategi membangun lingkungan belajar yang kondusif
Tabel 1. Kegiatan, Tujuan, Metode, Bahan dan Alat

\begin{tabular}{|c|c|c|c|c|}
\hline No & Kegiatan & Tujuan & Metode & $\begin{array}{c}\text { Bahan } \\
\text { dan Alat }\end{array}$ \\
\hline 1 & $\begin{array}{l}\text { Mengisi } \\
\text { angket } \\
\text { sebelum } \\
\text { kegiatan } \\
\text { penyuluha } \\
\text { n }\end{array}$ & $\begin{array}{l}\text { Mengetahui } \\
\text { minat } \\
\text { belajar } \\
\text { anak-anak } \\
\text { panti asuhan }\end{array}$ & $\begin{array}{l}\text { Mengisi } \\
\text { angket } \\
\text { berhubun } \\
\text { gan minat } \\
\text { belajar }\end{array}$ & $\begin{array}{l}\text { White } \\
\text { board, } \\
\text { spidol, } \\
\text { projector, } \\
\text { laptop, } \\
\text { kertas }\end{array}$ \\
\hline 2 & $\begin{array}{l}\text { Kontrak } \\
\text { belajar }\end{array}$ & $\begin{array}{l}\text { Memberika } \\
\text { n } \\
\text { pemahaman } \\
\text { tentang } \\
\text { tujuan dan } \\
\text { target } \\
\text { program } \\
\text { pengabdian } \\
\text { bersama tim } \\
\text { dan mitra }\end{array}$ & $\begin{array}{l}\text { Ceramah } \\
\text { dan } \\
\text { dikusi }\end{array}$ & $\begin{array}{l}\text { Whitebo } \\
\text { ard, } \\
\text { spidol, } \\
\text { projector, } \\
\text { laptop, } \\
\text { kertas }\end{array}$ \\
\hline 3 & $\begin{array}{l}\text { Penyuluh } \\
\text { an Tahap I } \\
\text { (meningk } \\
\text { atkan } \\
\text { prestasi di } \\
\text { sekolah) }\end{array}$ & $\begin{array}{l}\text { Membekali } \\
\text { mitra } \\
\text { mengenai } \\
\text { strategi } \\
\text { meningkatk } \\
\text { an prestasi } \\
\text { di sekolah }\end{array}$ & $\begin{array}{l}\text { Ceramah } \\
\text { dan } \\
\text { dikusi }\end{array}$ & $\begin{array}{l}\text { Whitebo } \\
\text { ard, } \\
\text { spidol, } \\
\text { projector, } \\
\text { laptop, } \\
\text { kertas }\end{array}$ \\
\hline 4 & $\begin{array}{l}\text { Penyuluh } \\
\text { an Tahap } \\
\text { II } \\
\text { (menumb } \\
\text { uhkan } \\
\text { minat } \\
\text { belajar) } \\
\end{array}$ & $\begin{array}{l}\text { Membekali } \\
\text { mitra } \\
\text { mengenai } \\
\text { startegi } \\
\text { menumbuhk } \\
\text { an minat } \\
\text { belajar }\end{array}$ & $\begin{array}{l}\text { Ceramah } \\
\text { dan } \\
\text { dikusi }\end{array}$ & $\begin{array}{l}\text { Whitebo } \\
\text { ard, } \\
\text { spidol, } \\
\text { projector, } \\
\text { laptop, } \\
\text { kertas }\end{array}$ \\
\hline 5 & $\begin{array}{l}\text { Penyuluh } \\
\text { an Tahap } \\
\text { III } \\
\text { (memban } \\
\text { gun } \\
\text { lingkunga } \\
\text { n belajar } \\
\text { yang } \\
\text { kondusif) }\end{array}$ & $\begin{array}{l}\text { Membekali } \\
\text { mitra } \\
\text { mengenai } \\
\text { startegi } \\
\text { membangun } \\
\text { lingkungan } \\
\text { belajar yang } \\
\text { kondusif }\end{array}$ & $\begin{array}{l}\text { Ceramah } \\
\text { dan } \\
\text { dikusi }\end{array}$ & $\begin{array}{l}\text { Whitebo } \\
\text { ard, } \\
\text { spidol, } \\
\text { projector, } \\
\text { laptop, } \\
\text { kertas }\end{array}$ \\
\hline 6 & $\begin{array}{l}\text { Mengisi } \\
\text { angketdan } \\
\text { Evaluasi }\end{array}$ & $\begin{array}{l}\text { Mengevalua } \\
\text { si tingkat } \\
\text { keberhasila } \\
\text { n program } \\
\text { pengabdian } \\
\text { masyarakat }\end{array}$ & $\begin{array}{l}\text { Mengisi } \\
\text { angket } \\
\text { setelah } \\
\text { diberikan } \\
\text { penyuluh } \\
\text { an }\end{array}$ & $\begin{array}{l}\text { White } \\
\text { board, } \\
\text { spidol, } \\
\text { projector, } \\
\text { laptop, } \\
\text { kertas }\end{array}$ \\
\hline
\end{tabular}

\section{HASIL DAN PEMBAHASAN}

Kegiatan Pengabdian ini dilaksanakan pada tanggal 7 September 2018 dan dibuka oleh Ketua Program Studi Pendidikan Bahasa Inggris. Setelah pembukaan, dilakukan kegiatan perkenalan dan pendekatan antara 
pelaksana dengan peserta sebagai mitra kegiatan pengabdian masyarakat . Respon dari peserta kegiatan sangat baik dan aktif bertanya. Sebelum dilaksanakan kegiatan ini, disebarkan angket kepada seluruh peserta untuk mengetahui minat belajar anak panti asuhan. Angket minat belajar anak panti asuhan adalah sebagai berikut:

Tabel 2. Kisi-Kisi Angket Minat Belajar Anak Panti Asuhan

\begin{tabular}{|c|c|c|}
\hline Variabel & Indikator & Butir Pernyataan \\
\hline \multirow[t]{3}{*}{$\begin{array}{l}\text { Minat } \\
\text { Belajar }\end{array}$} & $\begin{array}{l}\text { Perhatian } \\
\text { dalam KBM }\end{array}$ & $\begin{array}{l}\text { - Saya tidak berbicara } \\
\text { dengan teman ketika } \\
\text { guru mengajar } \\
\text { - Saya tidak } \\
\text { mengantuk ketika } \\
\text { guru mengajar } \\
\text { - Saya tidak bermain } \\
\text { sendiri ketika guru } \\
\text { mengajar }\end{array}$ \\
\hline & $\begin{array}{l}\text { Partisipasi } \\
\text { dalam KBM }\end{array}$ & $\begin{array}{l}\text { - Saya menjawab } \\
\text { pertanyaan yang } \\
\text { diberikan guru } \\
\text { - Saya bertanya } \\
\text { kepada guru jika ada } \\
\text { yang tidak } \\
\text { dimengerti } \\
\text { - Saya selalu maju di } \\
\text { depan kelas jika } \\
\text { disuruh guru }\end{array}$ \\
\hline & \begin{tabular}{|l} 
Perasaan \\
senang \\
terhadap \\
KBM
\end{tabular} & $\begin{array}{lrr}\text { - Saya } & \text { senang } & \text { ketika } \\
\text { guru } & \text { mengajar } \\
\text { dengan } & \text { metode } \\
\text { ceramah } & \\
\text { - Saya } & \text { senang } & \text { ketika } \\
\text { guru } & \text { mengajar } \\
\text { dengan } & \text { metode } \\
\text { diskusi } & \\
\text { - Saya } & \text { senang } & \text { ketika } \\
\text { guru } & \text { mengajar } \\
\text { dengan } & \text { metode } \\
\text { education games }\end{array}$ \\
\hline
\end{tabular}

Keterangan:

Setiap butir pernyataan memiliki pilihan jawaban sebagai berikut:
a. Ya, bernilai 3
b. Kadang-kadang, bernilai 2
c. Tidak, bernilai 1

Berdasarkan angket didapatkan hasil minat belajar anak yatim piatu di panti asuhan masih masih rendah. Hasil angket minat belajar dari 15 anak panti asuhan adalah sebagai berikut:

Tabel 3. Hasil Angket Sebelum Penyuluhan

\begin{tabular}{|l|l|c|}
\hline No & Nama & Jumlah nilai \\
\hline 1 & SRD & 15 \\
\hline 2 & AYS & 18 \\
\hline 3 & SST & 19 \\
\hline 4 & MFN & 17 \\
\hline 5 & DGT & 15 \\
\hline 6 & MFD & 19 \\
\hline 7 & CSS & 15 \\
\hline 8 & AFT & 16 \\
\hline 9 & IRP & 17 \\
\hline 10 & RAN & 15 \\
\hline 11 & SAH & 19 \\
\hline 12 & BSH & 20 \\
\hline 13 & NLR & 15 \\
\hline 14 & SFT & 19 \\
\hline 15 & YKD & 15 \\
\hline
\end{tabular}

Kegiatan pengabdian berlanjut dengan mengadakan Penyuluhan tahap I tentang meningkatkan prestasi di sekolah. Pada kegiatan ini peserta diberikan motivasi perlunya meningkatkan prestasi disekolah. Selanjutnya diadakan Penyuluhan tahap II tentang menumbuhkan minat belajar. Pada tahap ini peserta diberikan tips menumbuhkan minat belajar. Penyuluhan tahap III dengan topik membangun lingkungan belajar yang kondusif.

Pada tahap I, pemateri menjelaskan apa pentingnya prestasi dan cara yang dapat dilakukan untuk meningkatkan prestasi di sekolah. Pada tahap ini para peserta kegiatan sangat antusias mendengarkan pengarahan yang diberikan oleh pemateri. Para peserta juga merespon dengan bertanya kepada pemateri yang berhubungan dengan prestasi di sekolah.

Pada tahap II, pemateri menguraikan tentang bagaimana menumbuhkan minat belajar. Minat belajar dapat mempengaruhi prestasi siswa. Prestasi dapat diraih dengan adanya minat belajar yang tinggi. Minat belajar dapat ditumbuhkan dengan memberikan permainan yang berbasis edukasi kepada siswa. Permainan ini dapat dilaksanakan di sekolah atau di rumah. 
Permainan edukatif pada kegiaatn ini berhubungan dengan bahasa Inggris.

Pada permainan yang berbasis edukasi ini, para peserta terlihat antusias dengan permainan yang diberikan. Permainan edukasi itu antara lain word jumble race, hot seat and the mime. Ketiga permainan ini mengajarkan siswa untuk belajar kosa kata, tata bahasa, ejaan huruf, menulis, berbicara dan mendengarkan kata dan kalimat bahasa Inggris. Terlihat mereka sangat senang dan termotivasi belajar bahasa Inggris.

Pada tahap III, pemateri menjelaskan tentang menciptakan dan membangun lingkungan belajar yang kondusif bagi anak di panti asuhan. Pada tahap ini ditujukan kepada para pengasuh dan juga pengurus panti asuhan. Hal ini tidak kalah penting dengan tahap sebelumnya demi meningkatkan minat belajar dan prestasi anak panti asuhan.

Selama kegiatan berlangsung peserta kegiatan memiliki motivasi yang tinggi yaitu dengan sangat antusiasnya mereka mengikuti kegiatan penyuluhan. Hal tersebut menunjukkan bahwa adanya kesadaran para peserta tentang pentingnya meningkatkan minat belajar demi prestasi di sekolah. Antusias peserta kegiatan tampak pada gambar berikut ini:

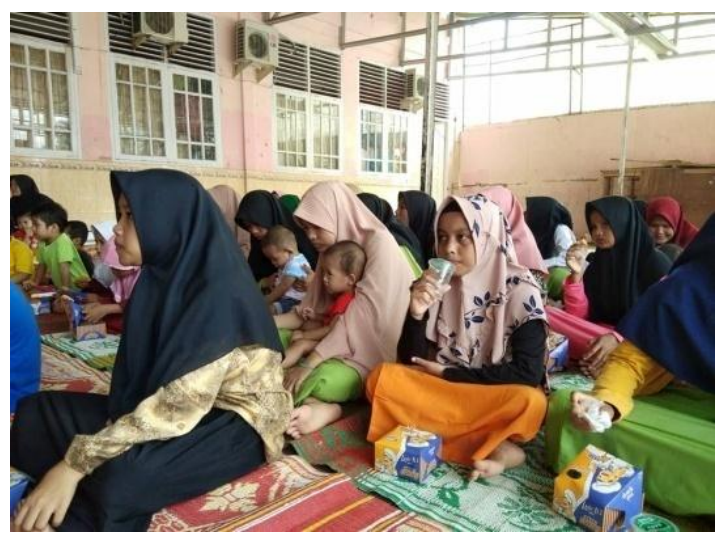

Gambar 1. Suasana Kegiatan

Untuk mengukur keberhasilan dan evaluasi kegiatan pengabdian kepada masyarakat ini, maka para peserta diminta mengisi angket yang telah disediakan pelaksana. Berdasarkan angket yang telah diisi oleh para anak panti asuhan, hasilnya menunjukkan bahwa minat belajar mereka mengalami peningkatan. Hal tersebut dapat dilihat pada tabel 4

Tabel 4. Hasil Angket Setelah Penyuluhan

\begin{tabular}{|l|l|c|}
\hline No & Nama & Jumlah nilai \\
\hline 1 & SRD & 17 \\
\hline 2 & AYS & 21 \\
\hline 3 & SST & 22 \\
\hline 4 & MFN & 19 \\
\hline 5 & DGT & 18 \\
\hline 6 & MFD & 22 \\
\hline 7 & CSS & 18 \\
\hline 8 & AFT & 19 \\
\hline 9 & IRP & 19 \\
\hline 10 & RAN & 17 \\
\hline 11 & SAH & 21 \\
\hline 12 & BSH & 22 \\
\hline 13 & NLR & 20 \\
\hline 14 & SFT & 23 \\
\hline 15 & YKD & 17 \\
\hline
\end{tabular}

Minat belajar anak di panti asuhan menjadi hal yang sangat penting diwujudkan oleh setiap anak. Hal ini sesuai dengan apa yang disampaikan Lestari (2015: 117) yang menyatakan bahwa dukungan minat belajar secara langsung dapat merubah perilaku belajar, dari tidak perduli menjadi lebih perduli. Dengan adanya minat belajar, anak akan meninggalkan kegiatan yang tidak bermanfaat demi meraih prestasi.

Minat belajar dapat meningkatkan prestasi anak panti asuhan di sekolah. Minat belajar perlu ditingkatkan pada setiap anak yang pada akhirnya akan berdampak pada peningkatan prestasi anak di sekolah. Sehingga dengan adanya program penyuluhan ini, para anak panti asuhan dan pengasuh merasa terbantu untuk meningkatkan minat belajar anak.

Para peserta merasakan manfaat kegiatan program pengabdian masyarakat (PPM) ini. Berdasarkan hasil yang didapat dari kegiatan pengabdian pada masyarakat (PPM), bisa dilihat bahwa kegiatan pengabdian ini mendapat respon yang sangat baik dari para peserta. 


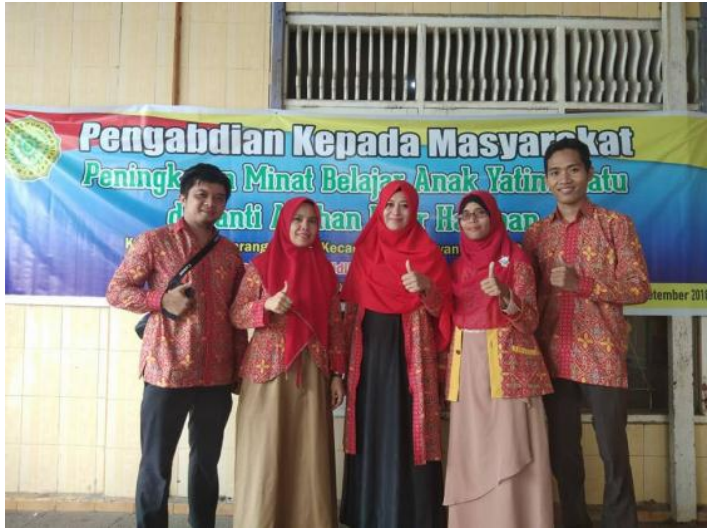

Gambar 2. Pelaksana Kegiatan

\section{SIMPULAN}

Peningkatan minat belajar anak bisa dilakukan dengan berbagai cara. Peningkatan minat belajar anak dapat diberikan dengan memberikan penyuluhan berupa strategi untuk meningkatkan minat belajar siswa. Strategi itu antara lain strategi meningkatkan prestasi belajar, strategi menumbuhkan minat belajar dan strategi membangun lingkungan belajar yang kondusif.

Untuk mengetahui minat belajar para anak di panti asuhan, telah diberikan angket untuk diisi oleh para peserta. Hasilnya menunjukkan bahwa minat belajar mereka masih rendah. Setelah diberikan penyuluhan, para peserta diminta mengisi angket minat belajar, hasilnya menunjukkan bahwa minat belajar mereka meningkat. Hal ini dilakukan untuk mengetahui keberhasilan kegiatan ini dan untuk mengevaluasi kegiatan Pengabdian kepada Masyarakat ini.

Para peserta kegiatan sangat berterima kasih kepada pelaksana kegiatan karena telah memberikan ilmu yang bermanfaat kepada para peserta. Oleh karena itu mereka berharap kegiatan ini tidak sampai disini saja, akan tetapi kegiatan ini tetap berlanjut diadakan oleh pelaksana.

Dengan diadakannya kegiatan Pengabdian kepada Masyarakat ini, tim pelaksana dari Program Studi Pendidikan Bahasa Inggris UMRI juga dapat menjalankan catur dharma perguruan tinggi dimana salah satu perannya adalah dengan melaksanakan Pengabdian kepada Masyarakat.

\section{UCAPAN TERIMA KASIH}

Kegiatan Pengabdian kepada Masyarakat ini tentunya tidak akan dapat terlaksana sesuai rencana jika tanpa bantuan dari berbagai pihak. Oleh karena itu penulis mengucapkan terima kasih kepada seluruh pihak yang telah membantu secara materil dan moril sehingga kegiatan pengabdian ini dapat terlaksana dengan baik. Ucapan terima kasih kami sampaikan kepada:

1. Rektor UMRI

2. Ketua LPPM UMRI

3. Dekan FKIP UMRI

4. Ketua Program Studi Pendidikan Bahasa Inggris

5. Ketua Yayasan Panti Asuhan Fajar Harapan

6. Anak Yatim Piatu Panti Asuhan Fajar Harapan

\section{DAFTAR PUSTAKA}

[1] Departemen Pendidikan dan Kebudayaan, Kamus Besar Bahasa Indonesia, Jakarta: Balai Pustaka, 2005

[2] Departemen Sosial Republik Indonesia, 2004

[3] Hadis, .Psikologi Dalam Pendidikan. Bandung. Alfabeta, 2008

[4] Lestari, Indah. "Pengaruh Waktu Belajar dan Minat Belajar Terhadap Hasil Belajar Matematika". E-Jurnal Formatif 3 (2): 115-125. ISSN: 2088$351 X$.

[5] Prayitno dan Erman Amti, DasarDasar Bimbingan dan Konseling, Jakarta: Rineka Cipta, 2004 